\title{
Correction to: Overweight and diabetes prevention: is a low-carbohydrate-high-fat diet recommendable?
}

\section{Fred Brouns ${ }^{1}$}

Published online: 16 April 2019

(C) The Author(s) 2019

\section{Correction to: \\ European Journal of Nutrition (2018) 57:1301-1312 https://doi.org/10.1007/s00394-018-1636-y}

In the original publication, the disclosure of potential conflicts of interest statement was not correct.

Please find below the correct statement:

\section{Potential conflict of interest}

The author spoke at a meeting of the European Starch Producers Association and EU commissioners (2017) about production and potential health effects of Iso-glucose. The author contributed to the Foundation-Kenniscentrum Suiker en Voeding (Knowledge Center Sugar and Food) for 2 evidence based educational videos about sugars, metabolism and health (2017) and prepared a text entitled "Voeding met een laag koolhydraat gehalte" (Food with a low carbohydrate content) for their educational newsletter (2018). The author took part in an invited expert panel (2015-2017) convened by ILSI-EUROPE with the aim to review international nutrition and food based guidelines about sugars, carbohydrates, fibers and health published in EJCN (https:// doi.org/10.1038/s41430-017-0035-4).

Open Access This article is distributed under the terms of the Creative Commons Attribution 4.0 International License (http://creativeco mmons.org/licenses/by/4.0/), which permits unrestricted use, distribution, and reproduction in any medium, provided you give appropriate credit to the original author(s) and the source, provide a link to the Creative Commons license, and indicate if changes were made.
The original article can be found online at https://doi.org/10.1007/ s00394-018-1636-y.

\section{Fred Brouns}

fred.brouns@maastrichtuniversity.nl

1 Department of Human biology, Faculty of Health, Medicine and Life Sciences, NUTRIM-School of Nutrition and Translational Research in Metabolism, Maastricht University, Post Box 616, 6200 MD Maastricht, The Netherlands 